\title{
PERSEPSI DOSEN TERHADAP LAYANAN APLIKASI E-LKD UIN AR-RANIRY DENGAN MENGGUNAKAN TECHNOLOGY ACCEPTENCE MODEL (TAM)
}

\author{
Andika Prajana ${ }^{1}$, Yuni Astuti ${ }^{2}$ \\ UIN Ar-Raniry,Banda Aceh,Indonesia \\ Universitas Negeri Padang, Sumatera Barat, Indonesia ${ }^{2}$ \\ Email : andikaprajana@ar-raniry.ac.id ${ }^{1},{ }^{2}$ yuniastuti@ fik.unp.ac.id ${ }^{2}$
}

\begin{abstract}
ABSTRAK
Teknologi informasi dan telekomunikasi memberikan pengaruh pada aktifitas pendidikan dari tingkat sekolah dasar maupun tingkat perguruan tinggi. Perguruan Tinggi merupakan lembaga formal yang diharapkan dapat melahirkan tenaga kerja kompeten yang siap menghadapi revolusi industri 4.0 seiring dengan kemajuan teknologi. Keahlian kerja, kemampuan beradaptasi dan pola pikir yang dinamis menjadi tantangan bagi sumber daya manusia, salah satunya sebagai dosen pada Perguruan Tinggi. Dalam upaya pengawasan mutu dosen di UIN Ar-Raniry Banda Aceh, Indonesia terhadap Tri Dharma Perguruan Tinggi mereka menggunakan aplikasi berbasis online E-LKD (Electronic "Laporan Kinerja Dosen"). Aplikasi ini dimanfaatkan sebagai sarana dalam pelaporan kegiatan per-semester dosen dan juga sebagai penilaian asesor lingkungan perguruan tinggi dalam memutuskan kelayakan tunjangan sertifikasi dan tunjangan remunerasi bagi dosen-dosen UIN ArRaniry. Tujuan meneliti ini adalah membuktikan secara empiris pengaruh antara variabel perceived usefulnes, technology support dan perceived ease of use terhadap attitude toward dan terhadap behavior intention dalam menggunakan fitur dan layanan dalam aplikasi E-LKD. Penelitian menggunakan metode studi kasus, dengan melihat karakteristik masalah yang berkaitan dengan latar belakang dan kondisi saat ini dari subjek yang diteliti, serta interaksinya dengan lingkungan. Penelitian ini menggunakan data kuisioner terhadap 100 orang dosen UIN-Raniry. Hasil dari penelitian ini menunjukkan bahwa variabel presepsi kemudahan, kualitas dukungan teknologi dan presepsi kegunaan secara parsial berpengaruh signifikan terhadap sikap dan perilaku dosen.
\end{abstract}

Kata Kunci: Manfaat yang dirasakan, TAM (Technology Acceptence Model)

\begin{abstract}
Information technology and telecommunications have an influence on educational activities from the elementary school level as well as the tertiary level. Higher Education is a formal institution that is expected to produce competent workforce that is ready to face the industrial revolution 4.0 along with technological advancements. Work skills, adaptability and a dynamic mindset become challenges for human resources, one of which is as a lecturer at tertiary institutions. In an effort to supervise the quality of lecturers at UIN Ar-Raniry Banda Aceh, Indonesia against the Tri Dharma of Higher Education they use an online application based on E-LKD (Electronic "Lecturer Performance Report"). This application is used as a tool in reporting semester activities of lecturers and also as an assessment of tertiary environmental assessors in deciding the eligibility of certification allowances and remuneration allowances for UIN Ar-Raniry lecturers. The purpose of this research is to empirically prove the influence between perceived usefulnes, technology support and perceived ease of use variables on attitude toward and behavior intention in using features and services in E-LKD applications. The research uses the case study method, by looking at the characteristics of the problems related to the background and current conditions of the subjects studied, as well as their interactions with the environment. This study uses questionnaire data on 100 UIN-Raniry lecturers. The results of this study indicate that the variable perceived ease, quality of technological support and usefulness perception partially have a significant effect on lecturers' attitudes and behavior.
\end{abstract}

Keywords: TAM (Technology Acceptence Model), perceived usefulnes

@Edukasi: Jurnal Ilmu Pendidikan FIP UPTT 2019

$\triangle$ Corresponding author :

Address :

Email :

ISSN 2656-8063 (Media Cetak)

Phone ISSN 2656-8071 (Media Online) 


\section{PENDAHULUAN}

Memanfaatkan teknologi sebagai saluran berkembangnya ilmu pengetahuan dan juga menciptakan manfaat praktis dan efisiensi terhadap perencanaan, proses dan evaluasi pendidikan. Perkembangan teknologi juga mempengaruhi gaya hidup masyarakat atau yang lebih kita kenal dengan istilah warganet sehingga bermunculan banyak inovasi di dunia teknologi sebagai contohnya adalah pemanfaatan gawai (gadget), surat elektronik (email), dan aplikasi pesan singkat (chatting) serta teknologi sosial media. Pada dasarnya teknologi dan sumber daya menjadi senjata paling efektif dalam memenuhi kebutuhan manusia yang tak terbatas, inovasi produk dan layanan baru menciptakan tantangan dan peluang yang sangat luas.(Lamb \& Hair, n.d.) Jaringan internet dalam teknisnya merupakan inovasi teknologi yang memecahkan masalah komunikasi ruang dan waktu antara satu sama lain. Menurut Lani Sidharta, pengertian internet adalah suatu bentuk interkoneksi dari sebuah jaringan komputer, dimana dapat memberikan bentuk layanan informasi secara lengkap. Lebih lanjut Lani mengatakan bahwa internet juga merupakan rekan maya atau virtual yang ampuh, yang biasa digunakan dalam media bisnis, politik, dan bahkan untuk hiburan semata. (Sidharta, 1996)

Pada tahun 2018 ketika Peringatan Hari Pendidikan Nasional muncul pembahasan Revolusi Industri 4.0 di berbagai kalangan. Revolusi industri 4.0 dalam pandangan Teknologi Informasi mengisyaratkan pada perubahan cara kerja dengan menitikberatkan pada pengelolaan data, sistem kerja industri melalui kemajuan teknologi terkini, komunikasi dan peningkatan efisiensi kerja terkait dengan interaksi manusia. Pengelolaan dan analisa data menjadi kebutuhan utama organisasi dalam proses pengambilan keputusan korporat yang terintegrasi oleh daya komputasi dan sistem penyimpanan data. Revolusi
Industri 4.0 inilah menjadi tantangan dan peluang perguruan tinggi sebagai lembaga formal yang diharapkan melahirkan tenaga kerja kompeten, profesional, mampu berkompetisi siap menghadapi industri kerja yang kian berkembang seiring dengan kemajuan teknologi. Keahlian kerja, kemampuan beradaptasi dan pola pikir yang dinamis menjadi tantangan bagi sumber daya manusia, salah satunya tenaga pendidik pada pendidikan formal di Perguruan Tinggi. Untuk menciptakan sumber daya manusia yang inovatif dan adaptif terhadap teknologi, sangat dibutuhkan penyesuaian sarana dan prasarana pembelajaran dalam hal yang berkaitan dengan teknologi informasi, internet, analisa big data dan komputerisasi. Perguruan tinggi dituntut memfasilitasi infrastruktur pembelajaran yang diharapkan mampu menghasilkan tenaga pendidik yang terampil dalam aspek literasi teknologi, literasi manusia dan literasi data.

UIN Ar-Raniry merupakan lembaga formal Pendidikan Tinggi yang berada di Banda Aceh Propinsi Aceh. Dalam perjalanannya UIN Ar-Raniry telah mengalami berbagai perkembangan dan kemajuan dalam berbagai bidang. Visi dan Misinya, Sumber Daya Manusia, Sarana dan Prasarana telah mengalami perkembangan sesuai dengan tuntutan zaman. UIN Ar-Raniry sendiri terdiri dari 9 Fakultas dan 43 Program Studi, sedangkan dosen nya berjumlah 541 orang. Dalam upaya pengawasan mutu dosen terhadap Tri Dharma Perguruan Tinggi, UIN ArRaniry sendiri menggunakan aplikasi berbasis online E-LKD. Aplikasi ini dimanfaatkan sebagai sarana dalam pelaporan kegiatan per-semester dosen dan juga sebagai penilaian asesor lingkungan perguruan tinggi dalam memutuskan kelayakan tunjangan sertifikasi dan tunjangan remunerasi bagi dosen-dosen UIN Ar-Raniry.

Aplikasi ini sudah mengalami berbagai perubahan dari aplikasi Microsoft Access ke 
aplikasi Web Base dimana dulunya dikerjakan secara manual dan sekarang sudah berbasis website atau online. Aplikasi ini menawarkan kemudahan dimana pemeriksaan berkas Laporan Kinerja Dosen oleh asesor tidak dibatasi oleh ruang dan waktu. Artinya, dosen tidak perlu bertemu asesor dalam verifikasi berkas karena dosen sudah meng-unggah semua berkas laporan kinerja mereka. Bertumbuh kembangnya layanan digital di dunia akademik berbasis aplikasi online merubah akan merubah perilaku tenaga pendidik/dosen, dimana dosen ini cepat memahami sebuah perubahan namun begitu juga cepat berkeluh kesah terhadap sesuatu yang dianggap tidak sesuai dengan kebutuhan yang dimiliki. Reaksi ini akan menimbulkan aksi yang merespon perilaku dosen menggunakan sebuah teknologi. (Martin Fishbein, 1981) mengemukakan bahwa persepsi dan reaksi seseorang terhadap sesuatu hal, akan menentukan sikap dan perilaku orang tersebut. Dari teori ini menghasilkan model perilaku sebagai suatu fungsi dari tujuan perilaku seseorang dan tujuan perilaku ditentukan oleh aspek sikap atas perilaku tersebut. (M Fishbein \& Ajzen, 1975) mengemukakan sebuah teori yaitu Theory of Reasoned Action (TRA) dimana aksi yang dilakukan seseorang dapat dilihat menggunakan variabel tertentu untuk mengukur perilaku yang terjadi. (Schierz, Schilke, \& Wirtz, 2010) berpendapat bahwa kerangka model TAM (Technology Acceptence Model) merupakan konstruk yang cukup akurat dalam mengukur dan mengadopsi sebuah teknologi. TAM merupakan teori turunan dari teori TRA. Maka dari permasalahan di atas peneliti menggunakan konstruk TAM untuk mengukur bagaimana Persepsi Reaksi dan Aksi Dosen UIN Ar-Raniry dalam menerima teknologi yang digunakan pada layanan E-LKD. Berdasarkan perumusan masalah di atas, maka tujuan yang diharapkan tercapai dalam penelitian ini adalah untuk membuktikan secara empiris:

1. Untuk mengetahui dan menguji pengaruh persepsi manfaat, persepsi kemudahan, dan persepsi kualitas teknologi terhadap sikap Dosen.

2. Untuk pengaruh persepsi manfaat, persepsi kemudahan, persepsi kualitas teknologi dan sikap Dosen terhadap Perilaku Dosen.

Untuk menguji dan mengetahui apakah persepsi manfaat, persepsi kemudahan, persepsi kualitas teknologi berpengaruh terhadap Perilaku Dosen melalui sikap Dosen dalam menggunakan fitur dan layanan yang ditawarkan dalam aplikasi E-LKD. (Sugihartono, Harahap, Setiawati, \& Nurhayati, 2007) menjelaskan persepsi adalah dimana otak memiliki kemampuan untuk menterjemah stimulus yang diinput kedalam indera manusia. Dari persepsi manusia ini terjadi perbedaan sudut pandang dalam penginderaan. Bisa diartikan bahwa ada yang mempersepsikan sesuatu itu baik dan ada juga yang buruk yang akan mempengaruhi tindakan nyata manusia. (Walgito \& Walgito, 2004) mengungkapkan bahwa persepsi lebih kepada proses pengorganisasian dan bagaimana menginterpretasikan stimulus yang diterima oleh individu sehingga menjadi sesuatu yang berarti. Stimulus yang direspon dari individu tergantung oleh perhatian individu tersebut. Berdasarkan hal tersebut, kemampuan berfikir, perasaan, dan pengalaman-pengalaman yang dimiliki individu tidaklah sama. (Waidi, 2006) mengungkapkan bahwa setiap orang mempunyai kecenderungan dalam melihat satu benda dalam waktu yang sama dengan cara yang berbeda-beda. Perbedaan itu dipengaruhi oleh pengetahuan, pengalaman dan sudut pandangnya. Persepsi juga berhubungan dengan cara pandang seseorang yang kemudian mereka akan berusaha untuk menafsirkannya. 
(Rakhmat, 2007) menyatakan persepsi adalah objek yang diamati dimana objek diperoleh dengan cara menyimpulkan informasi kemudian menafsirkan pesan. Sedangkan, Suharman (2005) menyatakan bahwa persepsi itu suatu cara menginterpretasikan informasi melalui sistem alat indera manusia.

Menurut (Sunaryo, 2004) syarat-syarat terjadinya persepsi adalah sebagai berikut:

1. Memiliki objek yang akan dipersepsikan

2. Fokus terhadap perhatian

3. Device/Alat Indra penerima stimulus

4. Saraf sensoris untuk melanjutkan stimulus ke otak

Dari penjelasan diatas terlihat bahwa objek yang dipersepsi harus fokus terhadap perhatian sehingga alat indra mampu menerima stimulus melalui saraf sensoris menuju otak untuk selanjutnya bisa diputuskan oleh otak dalam menarik kesimpulan. Menurut Bimo Walgito (2004) faktor-faktor yang berperan dalam persepsi dapat dikemukakan beberapa faktor, yaitu:

1. Objek yang dipersepsi

Objek menimbulkan stimulus yang menyentuh reseptor. Stimulus dapat datang dari individu lain yang mempersepsi, tetapi juga dapat datang dari dalam diri sendiri yang bersangkutan langsung mengenai syaraf penerima.

2. Alat indera, syaraf dan susunan syaraf

Alat indera atau reseptor merupakan sebuah alat penerima stimulus, kemudian ada saraf sensoris untuk meneruskan stimulus menuju pusat susunan saraf, yaitu otak sebagai pusat kesadaran sehingga membentuk persepsi seseorang.

\section{Perhatian}

Perhatian adalah langkah mewujudkan persepsi dan juga merupakan langkah utama sebagai suatu persiapan. Perhatian ini adalah konsentrasi dari seluruh kegiatan/aktifitas individu yang ditujukan pada sekumpulan objek.

Dari uraian diatas terdapat faktor-faktor dimana mewujudkan masing-masing persepsi individu berbeda meskipun objek yang dilihat itu persis sama. Persepsi personal maupun kelompok bisa jadi sangat berbeda meskipun situasinya sama. Hal ini timbul karena adanya perbedaan masingmasing personal atau kelompok dalam kepribadian, sikap dan juga motivasi yang dimiliki. Terbentuknya persepsi ini sudah jelas berproses dan terjadi dalam diri seseorang, namun persepsi juga terpengaruh dengan pengalaman, proses pembelajaran dan pengetahuannya. Pengolahan data dengan menjalankan fungsifungsi nya dengan perangkat komputer dikenal dengan istilah Pengolahan Data Elektronik (PDE). Pengolahan data (Data Processing) adalah proses merubah angka, huruf dan simbol sehingga menjadi data kemudian disajikan dalam bentuk informasi yang berguna dan lebih berarti. Definisi Pengolahan Data Elektronik (PDE) menurut (Bodnar \& Hopwood, 2004) yaitu sebagai berikut : "Elektronic Data Processing (EDP) is the use of computer technology to perform an organization transaction-oriented data processing. EDP is a fundamental accounting information system application in every organization. As computer technology has become common place, the term data processing (DP) has come to have the some meaning as EDP“.

Dari definisi diatas kita bisa mengartikan bahwa Pengolahan Data Elektronik (PDE) adalah memanfaatkan teknologi komputer dalam mengorganisasikan transaksi-transaksi pemrosesan data. Elektronic Data Processing adalah aplikasi sistem informasi akuntansi fundamental dalam setiap organisasi. Karena teknologi sudah mejadi hal yang biasa maka istilah pemprosesan data mulai dikenal dan mempunyai arti yang sama dengan Pengelolaan data elektronik. Dengan 
menggunakan pengolahan data dengan alat elektronik komputer, kita dapat menghasilkan data yang lebih informatif dan sangat berarti. Di dalam sebuah lembaga perguruan tinggi, dosen merupakan unsur terpenting dalam berjalannya kegiatan akademik dimana dosen merupakan tenaga pendidik yang secara profesional dan merupakan seorang ilmuwan yang memiliki tugas utama melaksanakan transformasi, kemudian mengembangkannya dan setelah itu menyebarluaskan ilmu pengetahuan, teknologi, dan seni melalui pendidikan dan pengajaran, penelitian dan pengabdian kepada masyarakat. Sedangkan untuk jabatan akademik tertinggi pada perguruan tinggi disebut dengan Profesor atau Guru Besar yang mempunyai kewajiban khusus seperti menulis buku dan karya ilmiah serta memberikan gagasannya dan berkotribusi untuk mencerahkan masyarakat. Tugas utama dosen adalah melaksanakan Tri Dharma Perguruan Tinggi dengan beban kerja paling sedikit sepadan dengan 12 (dua belas) sks (sistem kredit semester) dan paling banyak 16 (enam belas) sks pada setiap semester sesuai dengan kualifikasi akademiknya dengan ketentuan sebagai berikut (Pedoman BKD Dikti, 2010):

1. Tugas melaksanakan unsur pendidikan dan penelitian paling sedikit 9 (sembilan) sks atau 6 sks untuk pendidikan dan 3 sks untuk penelitian yang dilaksanakan pada Perguruan Tinggi dimana dia diberikan homebase/tempat NIDN (nomor induk dosen nasional) terdaftar.

2. Tugas melaksanakan pengabdian kepada masyarakat yang diselenggarakan baik oleh Perguruan Tinggi tempat bekerja atau lembagalembaga kemasyarakatan, LSM (Lembaga Swadaya Masyarakat), Komite-komite, atau organisasi kepemudaan sesuai dengan peraturan undang-undang yang berlaku.
3. Tugas unsur penunjang Tri Dharma yang dapat diperhitungkan bobot sks-nya sesuai dengan aturan yang ada.

4. Tugas pengabdian kepada masyarakat dan tugas penunjang ini paling sedikit setara dengan 3 (tiga) sks.

5. Tugas khusus kewajiban bagi profesor sekurang-kurangnya setara dengan 3 sks setiap tahun (2 semester).

Dosen yang mendapat penugasan sebagai pimpinan Perguruan Tinggi sampai dengan tingkat jurusan diwajibkan melaksanakan Dharma pendidikan paling sedikit sepadan dengan 3 (tiga) SKS. Pada tahun 1989 Fred D. Davis untuk pertama kalinya memperkenalkan Technology Acceptance Model (TAM). TAM ini dirancang khusus untuk pengguna sistem informasi sebagai pemodelan adopsi. Tujuan utama TAM untuk menelusuri beberapa pengaruh dari faktor eksternal terhadap kepercayaan, sikap, dan tujuan pengguna komputer. Model TAM ini dikembangkan dari model yang dimiliki oleh (Martin Fishbein \& Ajzen, 1980) yaitu model The Theory of Reasoned Action (TRA), dimana TRA ini merupakan teori tindakan yang beralasan dengan reaksi dan persepsi seseorang akan sesuatu hal, sehingga dapat menentukan sikap dan perilaku seseorang tersebut. Technology Acceptance Model (TAM) dikembangkan saat ini lebih menjelaskan kepada perilaku seseorang terhadap penggunaan teknologi dalam kehidupannya. Seirama dengan Theory of Reasoned Action (TRA), TAM juga merupakan teori perilaku yang mendasar dan berpengaruh terhadap tindakan yang dilakukan karena adanya minat atau rasa untuk ingin melakukan dan mengerjakannya.

(Jogiyanto, 2007) mengemukan bahwa ada tiga komponen dalam model TAM ini:

1. Minat berperilaku (behavioral intention)

Mengukur kekuatan tujuan untuk melakukan tindakan. Harus diketahui bahwa "minat 
299 Persepsi dosen terhadap layanan aplikasi E-LKD UIN AR-Raniry dengan menggunakan Technology Acceptence Model (TAM) - Andika Prajana, Yuni Astuti

perilaku" dan "perilaku” adalah dua hal yang berbeda. Jogiyanto (2007) juga menjelaskan bahwa Minat (intention) adalah keinginan untuk melakukan perilaku dan minat belum merupakan perilaku yang telah diwujudkan. Sedangkan perilaku (behavior) adalah tindakan nyata yang dilakukan.

2. Sikap (attitude)

(Martin Fishbein, 1981) mendefinisikan sikap (attitude) adalah perasaan individu untuk menerima ataupun menolak sebuah atau beberapa obyek atau perilaku dan diukur dengan sebuah prosedur yang memposisikan individu tersebut pada skala evaluasi dua pilihan "ya" ataupun "tidak". Jadi dapat disimpulkan sikap seseorang terhadap sistem informasi ataupun aplikasi, memperlihatkan seberapa jauh seseorang merasakan bahwa aplikasi itu baik atau tidak baik sama sekali. Jogiyanto (2007) menjelaskan sikap adalah sebagai evaluasi kepercayaan dari seseorang ketika menentukan perilaku yang akan dia lakukan.

3. Norma subjektif (subjective norm) yang mempengaruhi perilaku (behavior). Persepsi atau pandangan individu terhadap kepercayaan orang-orang lain yang nantinya mempengaruhi minat untuk melakukan atau tidak melakukan suatu perilaku.

Konsep persepsi kualitas (perceived quality), adalah salah satu penentu apakah dosen memanfaatkan secara maksimal atau keberatan dengan penggunaan aplikasi layanan ini. Dalam merancang aplikasi berkualitas ini sudah jelas menjadi faktor pertimbangan seorang dosen mengerjakan laporan kinerjanya, oleh karena itu banyak perguruan tinggi negeri ataupun swasta mengembangkan aplikasi-aplikasi berbasis online dengan kualitas untuk mewujudkan persepsi kualitas dosen yang baik juga terhadap aplikasi yang digunakannya. Kotler (2000) mengatakan bahwa : "Quality is the totality of feature and characteristics of a product or service that bear on its ability to satisfy stated or implied needs" Artinya, kualitas adalah totalitas nya sebuah fitur dan karakteristik yang memberikan kemampuan sebuah produk untuk memuaskan kebutuhan yang dinyatakan maupun tidak. Dari kesimpulan diatas timbul sebuah pertanyaan apakah aplikasi pada ELKD Dosen ini sudah memenuhi kebutuhan dosen dan perguruan tinggi itu, jawabannya tergantung pada penilaian subjektif dosen dimana masingmasing mereka memiliki nilai tersendiri terhadap kualitas, meskipun sulit untuk menjelaskan kualitas itu secara akurat

\section{METODE PENELITIAN}

Penelitian ini adalah studi kasus di UIN ArRaniry Banda Aceh, menggunakan metode kuantitatif dengan karakteristik yang berhubungan dengan latar belakang dan kondisi aktual dari subjek yang diteliti yaitu dosen, serta interaksi lingkungan perguruan tinggi. Dalam penelitian ini populasinya adalah dosen UIN Ar-Raniry. Dalam pengumpulan data, peneliti melakukan cara pengumpulan data dengan survei ke lapangan (field reasearch) dengan instrumen penelitian berupa Angket. Metode analisis pada penelitian ini menggunakan teknik analisis kuantitatif. Alat analisis yang digunakan adalah path analysis dengan bantuan progam IBM Statistical Package for Social Science (SPSS) Versi 23

\section{HASIL DAN PEMBAHASAN PENELITIAN}

Berdasarkan hasil pengolahan data maka ditemukan hasil dalam penelitian ini yaitu:

\section{Analisis pengaruh $X 1$ terhadap $Y$}

Dari analisis diatas diperoleh nilai signifikansi $\mathrm{X} 1$ sebesar $0,005<0,05$ sehingga dapat disimpulkan secara langsung bahwa X1 
300 Persepsi dosen terhadap layanan aplikasi E-LKD UIN AR-Raniry dengan menggunakan Technology Acceptence Model (TAM) - Andika Prajana, Yuni Astuti

berpengaruh signifikan terhadap Y. Dalam artian Persepsi Manfaat memiliki pengaruh terhadap Sikap Dosen.

2. Analisis pengaruh $\mathrm{X} 2$ terhadap $\mathrm{Y}$

Dari analisis diatas diperoleh nilai signifikansi X2 sebesar $0,007<0,05$ sehingga dapat disimpulkan secara langsung bahwa X2 berpengaruh signifikan terhadap Y. Dalam artian Persepsi Kemudahan memiliki pengaruh terhadap Sikap Dosen.

3. Analisis pengaruh X3 terhadap Y

Dari analisis diatas diperoleh nilai signifikansi X3 sebesar 0,189>0,05 sehingga dapat disimpulkan secara langsung bahwa X3 tidak berpengaruh signifikan terhadap Y. Dalam artian Persepsi Kualitas Teknologi tidak memiliki pengaruh terhadap Sikap Dosen.

4. Analisis pengaruh $X 1$ terhadap $Z$

Dari analisis diatas diperoleh nilai signifikansi $\mathrm{X} 1$ sebesar $0,184>0,05$ sehingga dapat disimpulkan secara langsung bahwa X1 tidak berpengaruh signifikan terhadap Z. Dalam artian Persepsi Manfaat tidak memiliki pengaruh terhadap Minat/Prilaku Dosen.

5. Analisis pengaruh $X 2$ terhadap $Z$

Dari analisis diatas diperoleh nilai signifikansi X2 sebesar 0,354>0,05 sehingga dapat disimpulkan secara langsung bahwa X2 tidak berpengaruh signifikan terhadap Z. Dalam artian Persepsi Kemudahan tidak memiliki pengaruh terhadap Minat/Prilaku Dosen.

6. Analisis pengaruh X3 terhadap Z

Dari analisis diatas diperoleh nilai signifikansi $\mathrm{X} 3$ sebesar 0,175 $>0,05$ sehingga dapat disimpulkan secara langsung bahwa X3 tidak berpengaruh signifikan terhadap Z. Dalam artian Persepsi Kualitas Teknologi tidak memiliki pengaruh terhadap Minat/Prilaku Dosen.
7. Analisis pengaruh $Y$ terhadap $Z$

Dari analisis diatas diperoleh nilai signifikansi $\mathrm{Y}$ sebesar $0,000<0,05$ sehingga dapat disimpulkan secara langsung bahwa $Y$ berpengaruh signifikan terhadap Z. Dalam artian Sikap Dosen memiliki pengaruh terhadap Minat/Prilaku Dosen.

8. Analisis pengaruh $\mathrm{X} 1$ melalui $\mathrm{Y}$ terhadap $\mathrm{Z}$ Pada analisis ini diperoleh pengaruh langsung yang diberikan oleh $\mathrm{X} 1$ terhadap $\mathrm{Z}$ sebesar 0,133. Sedangkan pengaruh tidak langsung X1 melalui $\mathrm{Y}$ terhadap $\mathrm{Z}$ adalah perkalian nilai beta $\mathrm{X} 1$ terhadap $\mathrm{Y}$ dengan nilai beta $\mathrm{Y}$ terhadap Z yaitu 0,291 x 0,451 =0,131. Maka total yang diberikan $\mathrm{X} 1$ yang diberikan terhadap $\mathrm{Z}$ adalah pangaruh langsung ditambah dengan pengaruh tidak langsung yaitu: $0,133+$ $0,131=0,264$. Berdasarkan hasil perhitugan diatas diketahui nilai pengaruh langsung 0,133 lebih besar dari pengaruh tidak langsung 0,131 yang berarti secara langsung Persepsi Manfaat melalui Sikap memiliki pengaruh terhadap Minat/Prilaku Dosen.

9. Analisis pengaruh $\mathrm{X} 2$ melalui $\mathrm{Y}$ terhadap $\mathrm{Z}$ Pada analisis ini diperoleh pengaruh langsung yang diberikan oleh $\mathrm{X} 2$ terhadap $\mathrm{Z}$ sebesar 0,095. Sedangkan pengaruh tidak langsung X2 melalui $\mathrm{Y}$ terhadap $\mathrm{Z}$ adalah perkalian nilai beta X2 terhadap $\mathrm{Y}$ dengan nilai beta $\mathrm{Y}$ terhadap $Z$ yaitu $0,291 \times 0,451=0,131$. Maka total yang diberikan X2 yang diberikan terhadap $\mathrm{Z}$ adalah pangaruh langsung ditambah dengan pengaruh tidak langsung yaitu: 0,95 + $0,131=0,226$. Berdasarkan hasil perhitugan diatas diketahui nilai pengaruh langsung 0,095 lebih kecil dari pengaruh tidak langsung 0,131 yang berarti secara tidak langsung Persepsi Kemudahan melalui Sikap memiliki pengaruh terhadap Minat/Prilaku Dosen. 
301 Persepsi dosen terhadap layanan aplikasi E-LKD UIN AR-Raniry dengan menggunakan Technology Acceptence Model (TAM) - Andika Prajana, Yuni Astuti

10.Analisis pengaruh X3 melalui Y terhadap Z

Pada analisis ini diperoleh pengaruh langsung yang diberikan oleh X3 terhadap $\mathrm{Z}$ sebesar 0,133. Sedangkan pengaruh tidak langsung X3 melalui $\mathrm{Y}$ terhadap $\mathrm{Z}$ adalah perkalian nilai beta X3 terhadap $\mathrm{Y}$ dengan nilai beta $\mathrm{Y}$ terhadap $\mathrm{Z}$ yaitu $0,138 \times 0,451=0,062$. Maka total yang diberikan X3 yang diberikan terhadap $\mathrm{Z}$ adalah pangaruh langsung ditambah dengan pengaruh tidak langsung yaitu: $0,133+$ $0,062=0,195$. Berdasarkan hasil perhitugan diatas diketahui nilai pengaruh langsung 0,133 lebih besar dari pengaruh tidak langsung 0,062 yang berarti secara langsung Persepsi Kualitas Teknologi melalui Sikap memiliki pengaruh terhadap Minat/Prilaku Dosen

\section{KESIMPULAN}

Berdasarkan hasil yang telah diperoleh maka penulis menyimpulkan:

1. Pada aspek manfaat dan kemudahan terdapat pengaruh terhadap Sikap dosen ini menandakan aplikasi yang memiliki manfaat dan mudah digunakan memberikan sikap yang positif kepada Dosen sedangkan Pada aspek kualitas teknologi tidak begitu berpengaruh terhadap sikap dosen, bisa jadi dengan perkembangan zaman kualitas yang dimiliki oleh antar aplikasi tidak begitu terasa perbedaannya.

2. Pengujian terhadap pengaruh persepsi manfaat, persepsi kemudahan, persepsi kualitas teknologi dan sikap Dosen terhadap Perilaku Dosen terlihat tidak adanya pengaruh sama sekali, hal ini kemungkinan terjadi dari tiga variabel manfaat, kemudahan dan kualitas secara langsung tidak merubah prilaku dosen karena aplikasi nya wajib digunakan sebagai sarana menilai kinerja dosen dalam Tri Dharma Perguruan Tinggi.
Pengujian selanjutnya adalah melihat persepsi manfaat, kemudahan dan kualitas teknologi terhadap prilaku dosen melalui sikap dosen. Dalam hal ini seluruh aspek berpengaruh signifikan terhadap prilaku dan ini menjelaskan bahwa sikap secara langsung memperlihatkan prilaku dosen terhadap minat dan kepercayaannya pada layanan aplikasi E-LKD.

\section{DAFTAR PUSTAKA}

Arikunto. (2006). Prosedur Penelitian Suatu Pendekatan Praktik. Jakarta: Rineka Cipta. Jakarta: Rineka Cipta.

Bodnar, G. H., \& Hopwood, W. S. (2004). Acconting Informations Systems, Ninth Editions. Pearson Education International.

Fishbein, M, \& Ajzen, I. (1975). Belief, attitude, intention and behavior: an introduction to theory and research.

Fishbein, Martin. (1981). leek Ajzen (1975), Belief, Attitude, Intention, and Behavior: An Introduction to Theory and Research. Reading, MA: Addison-Wesley.

Fishbein, Martin, \& Ajzen, I. (1980). Predicting and understanding consumer behavior: Attitude-behavior correspondence. Understanding attitudes and predicting social behavior, 148-172.

Jogiyanto. (2007). Sistem Informasi Keprilakuan. Yogyakarta: CV. Andi Offset.

Lamb, H., \& Hair, J. F. (n.d.). McDaniel. 2001. Pemasaran. buku, 1 .

Pedoman Penilaian Kinerja Dosen UPI, 2009

Pedoman BKD Dikti, 2010

Rakhmat, J. (2007). Persepsi Dalam Proses Belajar Mengajar. Jakarta: rajawali pers.

Schierz, P. G., Schilke, O., \& Wirtz, B. W. (2010). Understanding consumer acceptance of mobile payment services: An empirical analysis. Electronic commerce research and applications, 9(3), 209-216.

Sidharta, L. (1996). Internet: informasi bebas hambatan. Elex Media Komputindo. 
302 Persepsi dosen terhadap layanan aplikasi E-LKD UIN AR-Raniry dengan menggunakan Technology Acceptence Model (TAM) - Andika Prajana, Yuni Astuti

Sugihartono, F. K. N., Harahap, F., Setiawati, F. A., \& Nurhayati, S. R. (2007). Psikologi Pendidikan. Yogyakarta. UNY Press.

Sugiyono. (2010). Metode Penelitian Pendidikan. Bandung: Alfabeta.

Sunaryo. (2004). Psikologi Untuk Pendidikan. Jakarta: EGC.

Susanto, A. (2013). Sistem Informasi Akuntansi. Bandung: Lingga Jaya.

Toha, M. (2003). Perilaku Pendidikan dengan Pendekatan Baru. Bandung: PT Grafindo Persada.

Waidi. (2006). The Art of Re-engineering Your Mind for Success. Jakarta: Gramedia.

Walgito, B., \& Walgito, B. (2004). Pengantar psikologi umum. Andi. 